\title{
БИОЛОГИЧЕСКАЯ АКТИВНОСТЬ ФОСФОРНЫХ АНАЛОГОВ НИПЕКОТИНОВОЙ И ПИПЕКОЛИНОВОЙ КИСЛОТ
}

\author{
Н.А. Бондаренко ${ }^{1}$, Г.Н. Бондаренко ${ }^{2}$, О.Г. Ганина ${ }^{2}$ \\ ${ }^{1}$ Фонд «Развитие фармакологии эмоционального стресса», \\ 113054, Россия, Москва, 3-й Монетчиковский пер., 10/1. \\ ${ }^{2}$ Химический факультет, МГУ им.Ломоносова, \\ 119992, Россия, Москва, Ленинские горы, 1.
}

DOI: 10.19163/MedChemRussia2021-2021-102

E-mail:ninabonda52@gmail.com

Антиконвульсант Тиагабин, используемый для терапии эпилепсии у пациентов с КОВИД-19, с высокой вероятностью вызывает у них депрессивноподобное состояние, сопровождающееся когнитивными нарушениями в форме суицидальных мыслей [1]. В рамках поиска новых способов терапии интересной альтернативой могут являться производные пиперидина [2].

В настоящей работе нами синтезированы липофильные фосфорные аналоги нипекотиновой и пипеколиновой кислот (1-3).<smiles>CCOC1CCCCN1</smiles><smiles>CCOC1CCCNC1</smiles>
3<smiles>CCOC1CC(C(F)(F)F)CCN1</smiles>

Про- и антидепрессантное действие веществ оценивали в тестах «принудительное плавание» по Порсолту (ТПП) и «подвешивание за хвост» (ТПХ), а их влияние на когнитивные функции - в установке «Тест экстраполяционного избавления, ТЭИ). Ранее показано, что, в отличие от высоких доз психотомиметиков, препараты с седативным и миорелаксантным действием не влияют на способность животных в ТЭИ к решению задачи избавления из острой стрессогенной ситуации [3].

В ТПП и ТПХ фосфонат 1 продемонстрировал антидепрессантно-подобную активность, афосфонаты 2 и 3, наоборот, увеличивали длительность иммобильности животных. Фосфонат 3 нарушал способность к избавлению у крыс в ТЭИ. Таким образом, на этапе первичного скрининга был обнаружен интересный феномен принципиального различия биологической активности между 1 и 2 и, особенно, 3, что свидетельствует о важной роли природы и положения заместителя в пиперидиновом кольце (причем не только фосфонатного, но и трифторметильного).

\section{Литература}

[1] А.А. Холин, Н.Н. Заваденко, Е.А. Холина, и др. Рус. Мед. Ж.2020, 9, 13-17

[2] A. Seth, P. A. Sharma, A. Tripathi et al. Med.Chem. 2018, 14, 409-426

[3] Н.А. Бондаренко.Дисс. канд. биол. наук, М.,1992, 137 с.

$$
-102-
$$

